Vol. 9(6), pp. 109-116, 30 March, 2014

DOI: $10.5897 /$ IJPS2014.4125

Article Number: 78FC97543988

ISSN $1992-1950$

Copyright (C) 2014

International Journal of Physical

Author(s) retain the copyright of this article

Sciences

http://www.academicjournals.org/IJPS

\title{
Health risk assessment in relation to heavy metals in water sources in rural regions of South East Nigeria
}

\author{
Ekere Nwachukwu R. ${ }^{1 *}$, Ihedioha Janefrances N. ${ }^{1}$, Eze Ifeanyi S. $^{2}$ and Agbazue Vitus E. ${ }^{1}$ \\ ${ }^{1}$ Department of Pure and Industrial Chemistry, University of Nigeria, Nsukka, Enugu state, Nigeria. \\ ${ }^{2}$ Center for Energy Research and Development, University of Nigeria, Nsukka, Enugu state, Nigeria.
}

Received 3 February, 2014; Accepted 21 March, 2014

\begin{abstract}
This report presents a study of seven heavy metals concentrations in rural water supplies of South East region of Nigeria. The concentration levels of $\mathrm{As}, \mathrm{Hg}, \mathrm{Cd}, \mathrm{Pd}, \mathrm{Cr}, \mathrm{Cu}$ and $\mathrm{Fe}$ were evaluated in samples of water collected from the major water sources in the study area viz: streams, ponds/lakes and shallow hand dug wells. Flame Atomic Absorption Spectroscopy was used to assay the levels of $\mathrm{Fe}, \mathrm{Cu}, \mathrm{Cr}, \mathrm{Pb}$, $\mathrm{Cd}$ and As while cold vapour AAS was used for $\mathrm{Hg}$ determination. The human health risk assessment was performed by determining the water ingestion (IW), oral daily intake (DI), hazard quotient (HQ) and total hazard index (THI) of the metals from human oral consumption. The result of the analysis indicated the level ranges of the metals as follows $\mathrm{Hg}$. (0.00-0.01 ppm), As (0.010- -2.01 ppm); Cd (0.000.25 ppm); Pd (0.38-3.04 ppm) Cr (0.01-0.65 ppm); Cu (0.21-2.65 ppm) and Fe (0.75-15.01 ppm). The risk assessment results indicated that $\mathrm{HQ}$ of $\mathrm{As}, \mathrm{Cd}, \mathrm{Cr}$ and $\mathrm{Pb}$ were mostly of moderate risk, $(\mathrm{HQ}>1)$ while those of $\mathrm{Hg}, \mathrm{Fe}$ and $\mathrm{Cu}$ indicated no risk. The THI of all the water bodies assessed were of high risk except one river.
\end{abstract}

Key words: Hazard quotient, risk assessment, heavy metals, rural settlements, toxicity, south east, water sources, ingestion, oral daily intake.

\section{INTRODUCTION}

Over a billion people lack access to safe potable water supply globally and out of this number, more than 300 million people living in rural areas of sub-Saharan Africa are being affected (Bresine, 2007). Rural settlements in Nigeria are characterized by lack of potable water supply. This situation makes the dwellers depend on streams, natural ponds/ lakes, shallow hand dug wells and harvesting of rainfalls for their whole water needs. However, it is known that water resources in rural areas of Nigeria are prone to pollution either by low level of hygiene manifested by the inhabitants or by agricultural and local industrial activities of the inhabitants (Ikem et al., 2002; Adeleye and Adebiyi, 2003; Adekunle et al., 2007 ).

These rural areas are most often neglected by government as they lack basic infrastructure like potable water, health facilities, access roads, sanitation facilities and even electricity. The near absence of these facilities exposes the dwellers to a variety of health related risks. Contamination of water sources unarguably stands prominent among the many ills plaguing the rural settlements in developing countries.

Heavy metals pollution of water resources have been on front burners lately due to the health risks associated

*Corresponding author. E-mail: nwachukwuekere2006@yahoo.com

Author(s) agree that this article remain permanently open access under the terms of the Creative Commons Attribution License 4.0 International License 
with their presence. The major anthropogenic sources of heavy metals in rural aquatic environment are known to be agricultural activities, homes, local markets, abattoirs traditional industries such as blacksmithing, foundries, and smelling of metals and crude oil (Akujieze et al., 2003; Baccarelli and Bollati, 2009; Galadima et al., 2011; Kaitantzian et al., 2013). All these activities severe water sources quality by introducing harmful toxic metals into them. It is a common knowledge that majority of water sources in Nigeria available to local inhabitants are either unsafe or difficult to obtain and are stressed by poor management (Galadima et al., 2011). Hence about $60 \%$ of the South East Nigerians which live in rural areas continuously use water contaminated with all kinds of germs, heavy metals, and other pollutants enough to cause various diseases. The study of heavy metals contamination and their adverse effect on living organisms in aquatic environment and human beings have been widely studied all over the world (Singh et al., 2005; Nabi et al., 2007; Kimete et al., 2010; Nagehi, 2012). South Eastern Nigeria has a current population projection of 19,904,478 and cover an area of 28,821.56 $\mathrm{km}^{2}$ belonging to the forest savanna mosaic zone of Nigeria (NPC, 2006). Of this population 11,942,687 are rural dwellers.

The objectives of this present study were to: determine the present levels of seven heavy metals in the water samples; compare the obtained values with the WHO acceptable limits for those metals in potable water and assess the health risks of ingestion of the waters by the determination of their daily oral intake, hazard quotient (HQ) and total hazard index (THI). Currently no epidemiological study has been reported in these rural areas with regards to toxic metal poisoning.

\section{MATERIALS AND METHODS}

\section{Study area}

The study area, Uzouwani, lies between longitude $6^{\circ} 30^{1}$ and $7^{\circ} 00$ East and $6^{\circ} 55^{1}$ and $7^{\circ} 1^{1}$ North. Many rivers and streams abound in the area which belong to the Anambra river system and consist of 17 communities described as being $100 \%$ rural content (UPA, 2010). The dwellers draw almost all their water needs from streams, natural lakes/ponds and shallow hand-dug wells. These dwellers are $100 \%$ agriculturists and traditional industrialist and even civil workers practice one form of agricultural activity or the other. A sketch map of the study area showing the sampling stations is presented in Figure 1.

\section{Water sample collection}

The study area was divided into five agricultural cluster zones for the purposes of sample collection. Water samples were collected from three streams, twenty shallow hand dug wells (SHDW) and ten lakes/pond nearest to human settlements and most susceptible to anthropogenic influences. For each stream, six sampling status were created to capture the entry point of pollution sources and not in any way equidistant. Overall, 48 sampling points were created for the study and at each sampling time, 48 water samples were collected and analysed. The analysis was carried out once monthly over a period of four months between August and November, 2011. This gave a total of 192 determinations. The collection of water samples was done with $2 \mathrm{~L}$ polyethene bottles washed with detergents and copiously rinsed severally with deionized water. The water upon collection was acidified with few drops of concentrated nitric acid to keep the metals in solution. The samples were transported to the analytical laboratory in an ice-water mixture cooled boxes for analysis (Kimete et al., 2010).

\section{Equipment and chemicals}

Instrumental method was adopted using flame Atomic Absorption Spectrophotometer (Model UNICAM 929) with air /acetylene flame except for mercury where cold vapour was used. All chemicals used were analytical grade reagents. Standard solutions of the studied metals were prepared from their salts and used for calibration curve for $\mathrm{Fe}, \mathrm{Cu}, \mathrm{Cr}, \mathrm{Pb}, \mathrm{Cd}, \mathrm{As}$ and $\mathrm{Hg}$. Their standard solutions were prepared in aqueous solutions containing $2 \%$ of nitric acid. The determinations were carried out according to the standard methods for water quality (APHA, 1998).

The limit of detection for the metals were calculated as three times the standard deviation for the digested blanks $(n=5)$. Also the limit of quantiation LOQ was got as three times the LOD. The values of LOQ and LOD obtained are shown in Table 1.

\section{Health risk assessment}

The exposure of the rural dwellers to toxic metal contamination in the water samples were quantified using the equation developed by Bockting et al. (1996) to obtain the ingestion of water samples this ingestion of surface water $(\mathrm{mg} / \mathrm{kg} /$ day):

$[C W \times I R W \times E F \times A F] \div B W$

Where

IW = Injestion rate of surface water (litre/exposure day),

$\mathrm{EF}=$ Exposure frequency,

$\mathrm{AF}=$ Absorption factor,

$\mathrm{BW}=$ Body weight.

Health Risk assessment of the toxicants was interpreted based on the values of $\mathrm{HQ}$ and $\mathrm{THI}$. Values less than one $(\mathrm{HQ}$ or $\mathrm{THI}<1)$ means no risk and the greater the values above one, the greater is the level of risk of the toxicants manifesting long term health hazard effects increasing (Lemy, 1996 ; Wang et al., 2012).

The Hazard Quotient HQ was also estimated from the equation:

$\mathrm{HQ}=\frac{D}{R f D}$

where RfD in the oral reference dose or tolerable daily intake which was obtained from United States Environmental Protection Agency tables (USEPA - IRIS 2010) and refers to the maximum amount of toxicant which does not translate to adverse effect on the one ingesting the toxicants.

The parameters used in the calculation are shown in Table 2.

\section{RESULTS}

The results of the determinations are shown in Table 3 (Concentration of the trace heavy metals in the studied rivers), Table 4 (Concentration of the trace heavy metals in the studied ponds/lakes) and Table 5 (Concentration of 


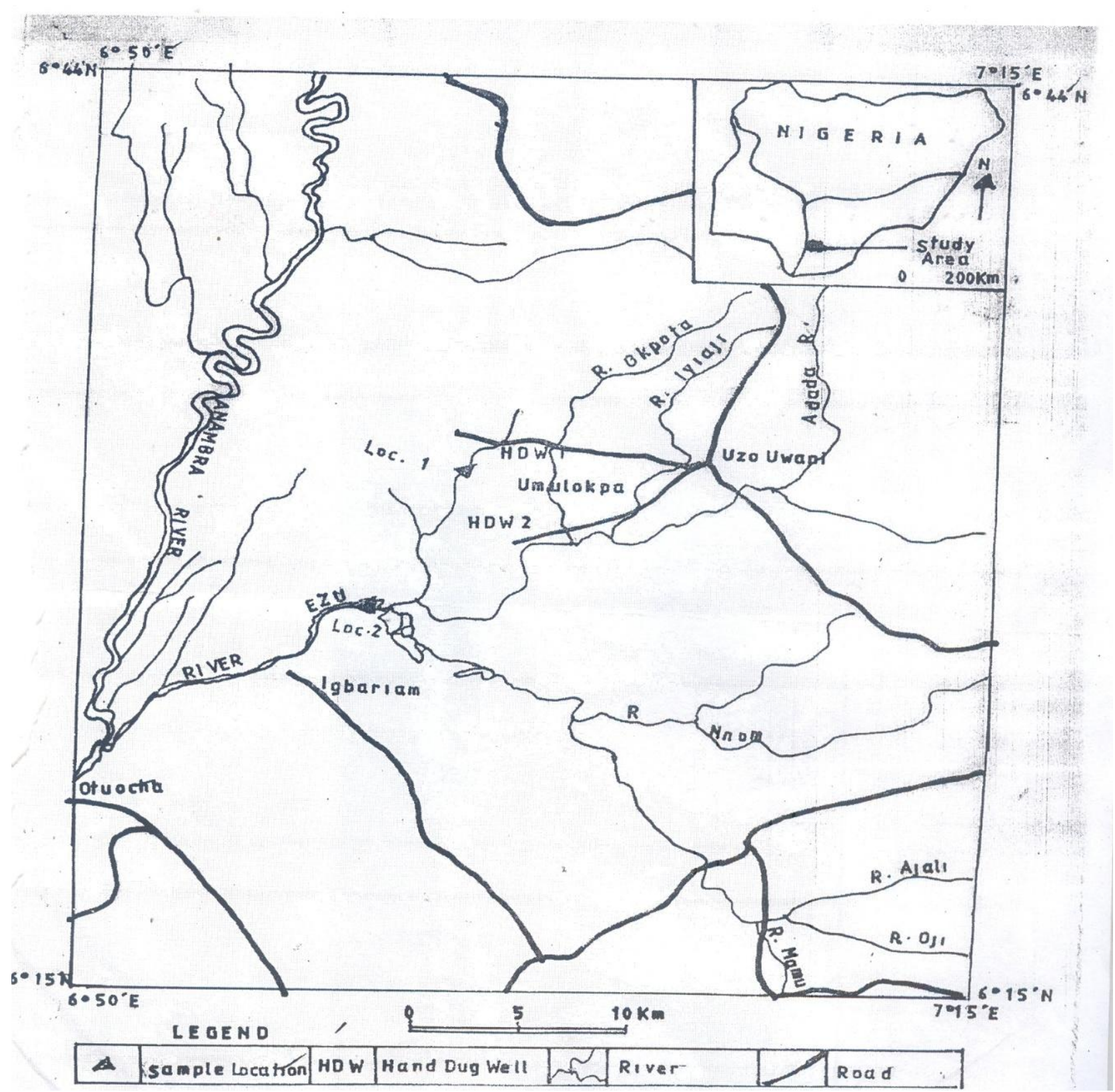

Figure 1. Sketch map of the study area showing sampling stations.

Table 1. Limit of Detection (LOD) and Limit of Quantitation (LOQ) of toxic metals and water samples using FAAS.

\begin{tabular}{lcc}
\hline Metal & LOD $(\mathbf{m g} / \mathbf{L})$ & LOQ $(\mathbf{m g} / \mathbf{L})$ \\
\hline $\mathrm{As}$ & 0.002 & 0.006 \\
$\mathrm{Hg}$ & 0.003 & 0.009 \\
$\mathrm{Cd}$ & 0.001 & 0.004 \\
$\mathrm{~Pb}$ & 0.002 & 0.006 \\
$\mathrm{Cr}$ & 0.003 & 0.009 \\
$\mathrm{Cu}$ & 0.002 & 0.006 \\
$\mathrm{Fe}$ & 0.005 & 0.010 \\
\hline
\end{tabular}

the trace heavy metals in the studied shallow hand dug wells). The concentration levels of total Arsenic had a range of 0.01 to $2.01 \mathrm{mg} / \mathrm{L}$. The metal was not detected in lyiakoro River and had a maximum concentration in Obina River. Highest concentration of arsenic occurred at Adani cluster ponds/lakes and Adani cluster shallow hand dug well. Mercury was not detected in majority of the water samples except in water samples from Adani clusters of ponds and shallow hand dug well where it has a maximum concentration of $0.001 \mathrm{mg} / \mathrm{L}$.

The cadmium levels in the water samples had ranges of 0.001 to $0.090 \mathrm{mg} / \mathrm{L}$; not detected (n.d) -1.00 and 0.002 - 
Table 2. Parameters used in the exposure equation.

\begin{tabular}{lccl}
\hline Parameter & Child & Adult & References \\
\hline IRW (litres/exposure day) & $50 \times 10^{-3}$ & $50 \times 10^{-3}$ & Van Wijnen (1982) \\
EF (days/365 days) & 30 & 30 & Albering et al. (1999) \\
AF (unitless) & 1 & 1 & Albering et al. (1999) \\
BW (kg) & 15 & 70 & Veerkamp and en Berge (1990) \\
\hline
\end{tabular}

Table 3. Concentration of the trace heavy metals in studied rivers.

\begin{tabular}{lcccc}
\hline Metallic lon (ppm) & Ezu & Obinna & lyiakoro & WHO Max limit \\
\hline $\mathrm{As}$ & $0.02 \pm 0.03$ & $0.08 \pm 0.011$ & $\mathrm{ND}$ & 0.050 \\
$\mathrm{Hg}$ & $\mathrm{ND}$ & $\mathrm{ND}$ & $\mathrm{ND}$ & 0.001 \\
$\mathrm{Cd}$ & $0.090 \pm 0.011$ & $0.015 \pm 0.011$ & $0.001 \pm 0.02$ & 0.003 \\
$\mathrm{~Pb}$ & $0.90 \pm 0.02$ & $0.40 \pm 0.11$ & $0.07 \pm 0.01$ & 0.050 \\
$\mathrm{Cr}$ & $0.44 \pm 0.02$ & $0.32 \pm 0.02$ & $0.01 \pm 0.11$ & 0.002 \\
$\mathrm{Cu}$ & $0.20 \pm 0.11$ & $0.45 \pm 0.02$ & $0.22 \pm 0.02$ & 1.000 \\
$\mathrm{Fe}$ & $1.80 \pm 0.12$ & $1.52 \pm 0.11$ & $1.40 \pm 0.11$ & 0.300 \\
\hline
\end{tabular}

ND $=$ Not Detected.

Table 4. Concentrations of the trace heavy metals in studied ponds/lakes.

\begin{tabular}{lcccccc}
\hline $\begin{array}{l}\text { Metallic } \\
\text { lon (ppm) }\end{array}$ & Adani & Opanda & $\begin{array}{c}\text { Pond/lake clusters } \\
\text { Ukpabi Nimbo }\end{array}$ & Umulokpa & Nkpologwu & $\begin{array}{c}\text { WHO Max. } \\
\text { limit }\end{array}$ \\
\hline $\mathrm{As}$ & $2.00 \pm 0.02$ & $1.00 \pm 0.03$ & $\begin{array}{c}0.070 \pm 0.03 \\
\mathrm{ND}\end{array}$ & $0.01 \pm 0.003$ & $0.060 \pm 0.03$ & 0.050 \\
$\mathrm{Hg}$ & $0.001 \pm 0.03$ & $\mathrm{ND}$ & $\mathrm{ND}$ & $\mathrm{ND}$ & 0.001 \\
$\mathrm{Cd}$ & $0.110 \pm 0.02$ & $0.050 \pm 0.003$ & $0.080 \pm 0.003$ & $\mathrm{ND}$ & $1.00 \pm 0.001$ & 0.003 \\
$\mathrm{~Pb}$ & $3.00 \pm 0.02$ & $2.54 \pm 0.03$ & $1.45 \pm 0.01$ & $0.99 \pm 0.02$ & $2.01 \pm 0.03$ & 0.050 \\
$\mathrm{Cr}$ & $0.65 \pm 0.02$ & $0.35 \pm 0.04$ & $0.20 \pm 0.15$ & $0.22 \pm 0.03$ & $0.35 \pm 0.03$ & 0.002 \\
$\mathrm{Cu}$ & $0.65 \pm 0.01$ & $0.32 \pm 0.01$ & $0.21 \pm 0.02$ & $0.28 \pm 0.02$ & $2.65 \pm 0.02$ & 1.000 \\
$\mathrm{Fe}$ & $0.75 \pm 0.01$ & $1.45 \pm 0.02$ & $4.50 \pm 0.01$ & $3.31 \pm 0.02$ & $6.50 \pm 0.03$ & 0.300 \\
\hline
\end{tabular}

ND $=$ Not Detected.

Table 5. Concentrations of the trace heavy metals in studied shallow hand dug wells (SHDW).

\begin{tabular}{lcccccc}
\hline $\begin{array}{l}\text { Metallic Ion } \\
\text { (ppm) }\end{array}$ & Adani & Opanda & Ukpabi Nimbo & Umulokpa & Nkpologwu & $\begin{array}{c}\text { WHO Max. } \\
\text { limit }\end{array}$ \\
\hline $\mathrm{As}$ & $1.85 \pm 0.02$ & $1.34 \pm 0.05$ & $0.87 \pm 0.03$ & $0.02 \pm 0.03$ & $0.05 \pm 0.011$ & 0.050 \\
$\mathrm{Hg}$ & $0.001 \pm 0.03$ & $\mathrm{ND}$ & $\mathrm{ND}$ & $\mathrm{ND}$ & $\mathrm{ND}$ & 0.001 \\
$\mathrm{Cd}$ & $0.25 \pm 0.001$ & $0.020 \pm 0.001$ & $0.115 \pm 0.030$ & $0.002 \pm 0.001$ & $0.95 \pm 0.10$ & 0.003 \\
$\mathrm{~Pb}$ & $3.54 \pm 0.03$ & $2.11 \pm 0.04$ & $0.65 \pm 0.04$ & $0.38 \pm 0.02$ & $0.66 \pm 0.01$ & 0.050 \\
$\mathrm{Cr}$ & $0.45 \pm 0.12$ & $0.15 \pm 0.01$ & $0.32 \pm 0.03$ & $0.08 \pm 0.12$ & $0.39 \pm 0.02$ & 0.002 \\
$\mathrm{Cu}$ & $0.90 \pm 0.02$ & $0.45 \pm 0.01$ & $0.65 \pm 0.03$ & $0.10 \pm 0.01$ & $0.33 \pm 0.02$ & 1.000 \\
$\mathrm{Fe}$ & $8.00 \pm 0.04$ & $7.10 \pm 0.03$ & $2.50 \pm 0.11$ & $1.45 \pm 0.01$ & $15.0 \pm 0.05$ & 0.300 \\
\hline
\end{tabular}

ND $=$ Not Detected.

$0.95 \mathrm{mg} / \mathrm{L}$ in rivers, ponds/lakes and hand dug wells respectively. The concentration levels of lead which ranged between 0.07 to $0.90 \mathrm{mg} / \mathrm{L} ; 0.99$ to $3.00 \mathrm{mg} / \mathrm{L}$ and 0.38 to $3.54 \mathrm{mg} / \mathrm{L}$ in rivers, ponds/lakes and hand dug wells respectively were higher in all the water samples than the set limit by WHO (2008). The levels of chromium were of the ranges 0.01 to $0.44 \mathrm{mg} / \mathrm{L} ; 0.20$ to $0.65 \mathrm{mg} / \mathrm{L}$ and 0.08 to $0.45 \mathrm{mg} / \mathrm{L}$ in rivers, ponds/lakes and hand 
dug wells respectively. The concentration levels of copper in the water bodies were 0.20 to $0.45 \mathrm{mg} / \mathrm{L} ; 0.21$ to $2.65 \mathrm{mg} / \mathrm{L}$ and 0.10 to $0.90 \mathrm{mg} / \mathrm{L}$ in rivers, ponds/lakes and hand dug wells respectively. In rivers, ponds/lakes and hand dug wells respectively. The concentration iron was found to be above the recommended level in domestic water use in all the water samples analyzed.

\section{DISCUSSION}

The arsenic concentrations were higher than the maximum set limit $(0.050 \mathrm{mg} / \mathrm{L})$ set by World Health Organization (WHO, 2008) for domestic water usage in all water samples except those from Ezu and lyiakoro Rivers, Umulokpa clusters of ponds/lakes and shallow hand dug wells. Arsenic enters water bodies through natural and anthropogenic sources. It enters ground water through the desorption of arsenic bound to iron oxides Arsenic is also used in various agricultural insecticides, herbicides, animal diseases prevention and growth stimulants for chicken and swine.

Epidemiological studies have suggested a correlation between chronic consumption of drinking water contaminated with arsenic and the incidence of all leading causes of mortality (Huet et al., 1975; Antman, 2001; Jones, 2007). The toxicological effects of arsenic in drinking have been recently reviewed by Moonis and Yuh-Shan (2011). The epidemiological record of arsenic in study area is totally lacking due to poverty, poor medical care and consequently absence of medical statistics.

The detected mercury in water samples from Adani clusters of ponds and shallow hand dug well were within the set limit by WHO which is, Agricultural Chemicals such as fumigants and preservers and local industries are the major sources of mercury in such rural water supplies. However, the presence of mercury at all calls for regular monitoring of the water bodies in this area. Exposure to mercury via food, water or fish or dental amalgam may raise the blood mercury levels which may lead to neurological damage in adults.

Cadmium is present as a pollutant in phosphate fertilizers and is also found in PVC products, colour pigment alloys and in re-chargeable nickel- cadmium batteries. These cadmium containing products are not recycled but dumped together with household waste, thereby polluting the environment. It has been established that an association exist between cadmium exposure and chronic renal failure (Bernard et al., 1992; Jarup et al., 1995; Hellstrom et al., 2001). Skeletal damage, which was first reported in Japan (called Itai-itai or ouch -ouch) was as a result of using cadmium contaminated water for irrigation of local rice fields. Several other reports have suggested that a relatively low cadmium exposure may give risk to skeletal damage (Alfven et al., 2000; Nordberg et al., 2002).

The concentration levels of lead were higher in all the water samples than the set limit by WHO. This discovery portends serious danger to the inhabitants of the study area. Adults take up to 10 to $15 \%$ of lead in food and water whereas children may absorb up to $50 \%$ through the gastro intestinal tract. Lead is accumulated in the skeleton with a half life in the skeleton of 20 to 30 years (WHO, 1995). The symptoms of acute lead poisoning are headache, irritability, abdominal pain and numerous symptoms related to nervous system. Recent researches have shown long term lead exposure in children may results in diminished intellectual capacity, encephalopathy, acute psychosis, concentration and learning difficulties and reduced ability to understand (WHO, 1995). Though epidemiological data of lead poisoning is totally absent in the study area due to high level of poverty, neglect, near absence of medical facilities and superstitious beliefs, the possibility of presence of symptoms of lead poisoning in the studied area is strongly speculated (Ubachukwu, 2004).

The concentration iron was found to be above the recommended level in domestic water use in all the water samples analyzed. Excess iron in water and food constitute health hazard, to people. Chronic consumption of water with iron overload results in gene mutation leading to haemochromatosis whose symptoms include fatigue, weight loss, joint pains and ultimately heart disease, liver problems and diabetes (US-CDC, 2011). Furthermore, iron in water also causes severe allergic reaction (rash, lives, itching), difficulty in breathing, tightness in chest, swelling of the mouth, lips and face, black tarry stools and blood or streaks of blood in the stool and severe vomiting or stomach pain (US-CDC, 2011).

Except in Nkpologwu cluster of ponds/lakes, the concentration levels of copper in the water bodies were within the set limit. The main sources of copper in rural water bodies include local industries effluents, domestic wastewater, fumigation and agrochemicals and weathering of copper bearing rocks. All these activities take place in the studied area which may be the reasons for slight elevation of copper levels in the water samples. Like other toxic metals, long term exposure to copper can cause irritation of nose, mouth and eyes which can lead to headache, stomachache, dizziness, vomiting and diarrhea among other health hazards.

The levels of chromium in the water samples were all higher than the set limit except for lyiakoro river. Water containing chromium ions in excess of the set limit may have an erythropoietin effect such as increased occurrence of goiter among humans and animals (Oyeku and Eludoyin, 2010).

Similar studies in some rural settlements showed elevated levels of toxic metals in rural ground and surface water sources (Adekunle et al., 2007; Ogunlaja and Ogunlaja, 2007; Nwagozie and Ogelle, 2007). This situation is a source of worry considering the fact that typical rural community in Nigeria is devoid of basic infrastructures that make life worth living. 
Table 6. Ingestion of water (IW) $\left(\times 10^{-2}\right)$, Oral Daily Intake (DI) $\left(\times 10^{-2}\right)$, Hazard Quotient (HQ) and Total hazard index (THI) of Heavy metal of the water samples

\begin{tabular}{|c|c|c|c|c|c|c|c|c|c|}
\hline Variable & & $\mathbf{A g}$ & $\mathrm{Hg}$ & Cd & $\mathrm{Pb}$ & $\mathrm{Cr}$ & $\mathrm{Cu}$ & $\mathrm{Fe}$ & THI \\
\hline \multirow{4}{*}{ Ezu River } & IW $\mathrm{Whild}_{\text {ch }}$ & 0.020 & \multirow{4}{*}{ ND } & 0.09 & 0.900 & 0.44 & 0.20 & 1.80 & \multirow{4}{*}{11.535} \\
\hline & IW $W_{\text {adult }}$ & 0.004 & & 0.019 & 0.193 & 0.094 & 0.043 & 0.385 & \\
\hline & DI & 0.041 & & 0.84 & 1.83 & 0.899 & 0.408 & 3.68 & \\
\hline & $\mathrm{HQ}$ & 1.362 & & 1.84 & 5.22 & 3.00 & 0.702 & 0.053 & \\
\hline \multirow{4}{*}{ Obinna River } & $\mathrm{IW}_{\text {child }}$ & 0.08 & \multirow{4}{*}{ ND } & 0.015 & 0.4 & 0.32 & 0.45 & 1.52 & \multirow{4}{*}{6.027} \\
\hline & $\mathrm{IW}_{\text {adult }}$ & 0.017 & & 0.003 & 0.086 & 0.068 & 0.386 & 0.325 & \\
\hline & DI & 0.163 & & 0.137 & 0.817 & 0.653 & 0.096 & 3.104 & \\
\hline & $\mathrm{HQ}$ & 0.543 & & 0.613 & 2.33 & 2.18 & 0.317 & 0.044 & \\
\hline \multirow{4}{*}{$\begin{array}{l}\text { lyiakoro } \\
\text { River }\end{array}$} & $\mathrm{IW}_{\text {child }}$ & & \multirow{4}{*}{ ND } & 0.001 & 0.07 & 0.010 & 0.22 & 1.40 & \multirow{4}{*}{0.752} \\
\hline & $\mathrm{IW}_{\text {adult }}$ & & & 0.0002 & 0.015 & 0.002 & 0.047 & 0.30 & \\
\hline & DI & ND & & 0.002 & 0.143 & 0.020 & 0.449 & 2.86 & \\
\hline & $\mathrm{HQ}$ & & & 0.041 & 0.409 & 0.068 & 0.112 & 0.041 & \\
\hline \multirow{4}{*}{$\begin{array}{l}\text { Adani Lakes/ ponds } \\
\text { clusters }\end{array}$} & $\mathrm{IW}_{\text {child }}$ & 1.000 & \multirow{4}{*}{ ND } & 0.110 & 3.00 & 0.65 & 0.65 & 0.75 & \multirow{4}{*}{78.224} \\
\hline & $\mathrm{IW}_{\text {adult }}$ & 0.214 & & 0.023 & 0.642 & 0.139 & 0.139 & 0.161 & \\
\hline & DI & 2.040 & & 0.225 & 1.10 & 1.327 & 1.327 & 1.531 & \\
\hline & $\mathrm{HQ}$ & 68.076 & & 2.246 & 3.130 & 4.425 & 0.332 & 0.02 & \\
\hline \multirow{4}{*}{$\begin{array}{l}\text { Opanda Lakes/ponds } \\
\text { Clusters }\end{array}$} & IW $\mathrm{W}_{\text {child }}$ & 0.5 & \multirow{4}{*}{ ND } & 0.05 & 2.54 & 0.35 & 0.32 & 0.310 & \multirow{4}{*}{58.068} \\
\hline & $\mathrm{IW}_{\text {adult }}$ & 0.107 & & 0.011 & 0.543 & 0.075 & 0.068 & 2.96 & \\
\hline & $\mathrm{DI}$ & 1.02 & & 0.102 & 7.146 & 0.715 & 0.653 & 0.70 & \\
\hline & $\mathrm{HQ}$ & 34.04 & & 1.021 & 20.419 & 2.383 & 0.163 & 0.042 & \\
\hline \multirow{4}{*}{$\begin{array}{l}\text { Akpabi } \\
\text { Lakes/ponds } \\
\text { Clusters }\end{array}$} & $\mathrm{IW}_{\text {child }}$ & 0.07 & \multirow{8}{*}{ ND } & 0.08 & 1.45 & 0.20 & 0.21 & 4.50 & \multirow{4}{*}{16.461} \\
\hline & $\mathrm{IW}_{\text {adult }}$ & 0.015 & & 0.017 & 0.310 & 0.043 & 0.044 & 0.903 & \\
\hline & $\mathrm{DI}$ & 0.142 & & 0.163 & 2.961 & 0.408 & 0.429 & 9.19 & \\
\hline & $\mathrm{HQ}$ & 4.77 & & 1.63 & 8.461 & 1.362 & 0.107 & 0.131 & \\
\hline \multirow{4}{*}{$\begin{array}{l}\text { Umulokpa } \\
\text { Ponds/lakes } \\
\text { Clusters }\end{array}$} & $\mathrm{IW}_{\text {child }}$ & 0.01 & & & 0.99 & 0.22 & 0.28 & 3.51 & \multirow{4}{*}{10.359} \\
\hline & $\mathrm{IW}_{\text {adult }}$ & 0.002 & & & 0.212 & 0.047 & 0.060 & 0.708 & \\
\hline & DI & 0.02 & & ND & 2.78 & 0.449 & 0.572 & 6.76 & \\
\hline & $\mathrm{HQ}$ & 400.68 & & & 7.96 & 1.498 & 0.143 & 0.09 & \\
\hline \multirow{4}{*}{ Nkpologwu (SHDW) } & IW $\mathrm{Whild}_{\mathrm{c}}$ & 0.06 & \multirow{4}{*}{ ND } & 1.00 & 2.01 & 0.35 & 2.65 & 6.50 & \multirow{4}{*}{40.156} \\
\hline & $\mathrm{IW}_{\text {adult }}$ & 0.013 & & 0.214 & 0.430 & 0.075 & 0.567 & 1.39 & \\
\hline & DI & 0.123 & & 2.042 & 4.105 & 0.715 & 5.412 & 0.132 & \\
\hline & $\mathrm{HQ}$ & 4.084 & & 20.42 & 11.728 & 2.383 & 1.352 & 0.190 & \\
\hline \multirow{4}{*}{ Adani (SHDW) } & IW $\mathrm{Whild}_{\mathrm{f}}$ & 1.85 & 0.004 & 0.25 & 3.54 & 0.45 & 0.90 & 8.0 & \\
\hline & IW $W_{\text {adult }}$ & 0.40 & 0.0008 & 0.054 & 0.758 & 0.96 & 0.193 & 1.71 & \\
\hline & $\mathrm{DI}$ & 3.78 & 0.008 & 0.511 & 7.22 & 0.919 & 1.83 & 16.3 & 156.222 \\
\hline & $\mathrm{HQ}$ & 125.94 & 0.766 & 5.105 & 20.655 & 3.063 & 0.460 & 0.233 & \\
\hline & $\mathrm{IW}_{\text {child }}$ & 1.34 & & 0.02 & 2.11 & 0.15 & 0.45 & 7.10 & \\
\hline & IW $W_{\text {adult }}$ & 0.287 & & 0.004 & 0.452 & 0.032 & 0.096 & 1.519 & \\
\hline Opanda SHDW & $\mathrm{DI}$ & 2.74 & ND & 0.041 & 4.30 & 0.306 & 0.919 & 14.70 & 105.400 \\
\hline & $\mathrm{HQ}$ & 91.22 & & 0.408 & 12.312 & 1.02 & 0.230 & 0.210 & \\
\hline
\end{tabular}


Table 6. Contd.

\begin{tabular}{|c|c|c|c|c|c|c|c|c|c|}
\hline & $\mathrm{IW}_{\text {child }}$ & 0.87 & \multirow{4}{*}{ ND } & 0.115 & 0.65 & 0.32 & 0.65 & 2.50 & \multirow{4}{*}{67.959} \\
\hline Ukpabi Nimbo SHDW & $\mathrm{IW}_{\text {adult }}$ & 0.186 & & 0.025 & 0.139 & 0.068 & 0.139 & 0.535 & \\
\hline \multirow{2}{*}{ Cluster } & DI & 1.78 & & 0.235 & 1.32 & 0.654 & 1.327 & 5.70 & \\
\hline & $\mathrm{HQ}$ & 59.233 & & 2.345 & 3.79 & 2.178 & 0.332 & 0.081 & \\
\hline \multirow{4}{*}{$\begin{array}{l}\text { Umulokpa } \\
\text { SHDW } \\
\text { Cluster }\end{array}$} & $\mathrm{IW}_{\text {child }}$ & 0.02 & \multirow{4}{*}{ ND } & 0.002 & 0.38 & 0.08 & 0.10 & 1.45 & \multirow{4}{*}{4.627} \\
\hline & IW $\mathrm{Wdult}_{\mathrm{a}}$ & 0.004 & & 0.004 & 0.081 & 0.0177 & 0.021 & 0.310 & \\
\hline & DI & 0.04 & & 0.039 & 0.776 & 0.163 & 0.281 & 2.96 & \\
\hline & $\mathrm{HQ}$ & 1.36 & & 0.393 & 2.217 & 0.545 & 0.070 & 0.042 & \\
\hline \multirow{4}{*}{$\begin{array}{l}\text { Nkpologwu } \\
\text { SHDW } \\
\text { Cluster }\end{array}$} & $\mathrm{IW}_{\text {child }}$ & 0.05 & \multirow{4}{*}{ ND } & 0.95 & 0.66 & 0.39 & 0.33 & 15.0 & \multirow{4}{*}{29.911} \\
\hline & $\mathrm{IW}_{\text {adult }}$ & 0.011 & & 1.203 & 0.141 & 0.083 & 0.071 & 0.321 & \\
\hline & DI & 0.102 & & 1.94 & 1.348 & 0.796 & 0.674 & 30.6 & \\
\hline & $\mathrm{HQ}$ & 3.40 & & 19.401 & 3.851 & 2.654 & 0.168 & 0.438 & \\
\hline
\end{tabular}

$\mathrm{ND}=$ not detected, $\mathrm{SHDW}=$ shallow hand dug well.

\section{Health risk assessment}

The calculated ingestion of water (IW) for both child and adult, daily oral intake (DI), hazard quotient (HQ) and total hazard index (THI) are presented in Table 6. The result of the potential risk assessment calculations showed the Arsenic had hazard quotient $(\mathrm{HQ})$ ranges of 0.543 to 125.94 while only three water bodies (lyiakwo River, Obinna River and Umulokpa ponds/lake dusters) have values that pose no health risk to the rural dwellers who depend on them for drinking and cooking of their foods $(\mathrm{HQ}<1)$. Total mercury was detected only in Adani shallows hand dug well cluster but its $\mathrm{HQ}$ is not yet a risk factor. The $\mathrm{HQ}$ for $\mathrm{Cd}$ in five out of the thirteen water body clusters studied indicated no risk while the rest pose potential risk for the users. The hazard index for $\mathrm{Pb}$ was high in all water samples except lyiakoro river $(\mathrm{HQ}=$ 0.409). $\mathrm{Cr}$ had $\mathrm{HQ}$ values has than one in only two sample clusters while the rest pose moderate risk to the water users. $\mathrm{Cu}$ and $\mathrm{Fe}$ pose no hazard risk in all the water bodies except for Nkpologwu ponds where $\mathrm{HQ}$ value for $\mathrm{Cu}$ was 1.352, an indication of moderate risk.

The Total Hazard Index (THI) of the metals in all the water bodies studied show high risk except in lyiakoro River $(\mathrm{THI}=0.752)$ with the highest risk in Adani shallow hand dug well cluster $(\mathrm{THI}=156.222)$. This result is a source of concern because of possible heavy metal bioaccumulation among the consumers of these water bodies. Similar risk assessments carried out by Muhammed et al. (2011) found HQ values less than unity for drinking waters of Kohistan region of Pakistan. Chromium (IV) was found by Kelepertzis (2014) to be of serious concern in drinking waters of Thiva area of Greece.

\section{Conclusion}

Seven toxic metals were assessed in water sources in the rural settlements. The results of the assay showed that except for mercury, all others showed presence in excess of set limit in most of the water samples. The hazard risk assessment of the water samples indicated moderate risk for some and high risk for others.

\section{Conflict of Interests}

The author(s) have not declared any conflict of interests.

\section{REFERENCES}

Adekunle M, Adetunji MT, Gbadebo AM, Banjoko B (2007). Assessment of groundwater quality in a typical rural settlement in South West, Nigeria. Int. J. Environ Res. J. Public Health. 4:307-318. http://dx.doi.org/10.3390/ijerph200704040007

Adeleye IA, Adebiyi A (2003). A physicochemical and microbial assessment of Oko-Oba-a Nigerian abattoir. J. Environ. Biol. 24:309313.

Akujieze CN, Coker SJ, Oteze GE (2003). Ground Water in Nigeria millennium experience - Distribution, practice, problems and solutions. Hydrogeol. J. 1:59-274.

Albering HJ, Rila JP, Moonen EJC, Hoogewerff JA, Kleinjans JCS (1999). Human Health Risk Assessment in Relation to Environmental Pollution of Two Artificial Fresh water Lakes in the Netherlands. Environmental Health Perspective. 107:27-35. http://dx.doi.org/10.1289/ehp.9910727

Alfven T, Elinder CG, Carlsson MD, Grubb A, Hellstrom L, Persson B (2000). Low -level Cadmium exposure and Osteoporosis. J. Bone Miner. http://dx.doi.org/10.1359/jbmr.2000.15.8.1579

Antman KH (2001). The History of Arsenic Trioxide in Cancer Therapy. The Oncologist. 6(suppl. 2):1-2. http://dx.doi.org/10.1634/theoncologist.6-suppl_2-1

American Public Health Association. (APHA) (1998). Standard Methods for the examination of water and waste water. 20th Edition. AWWA/NPCF. New York 5:24-26.

Baccarelli A, Bollati V (2009). Epigenetic and environmental Chemicals. Current Opinion in Pediatrics 21:243-251. http://dx.doi.org/10.1097/MOP.0b013e32832925cc

Bernard A, Roles H, Buchel JP, Cardenas A, Lauwery R (1992). Cadmium and Health: the Belgian experience. IARC Scientific publications. 118:15-23. 
Bockting GJM, Koolenbander JGM, Swarjes FA (1996). SEDSOIL. Estimation of human exposure to sediments (in Dutch) Rpt no 715810011. Bilthoven. The Netherlands Institute of public Health and the environment.

Bresine E (2007). Sustainable water supply in developing countries. Geol. Soc. Amer. Paper No. 194-201

Galadima A, Garba ZN, Leke L, Almustapha M, Adams IK (2011). Domestic water Pollution among Local Communities in Nigeria Causes and Consequences. Euro. J. Sci. Res. 52:592-563.

Hellstrom L, Elinder CG, Dahlberg B (2001). Cadmium Exposure and end-stage renal disease. Am. J. Kidney Dis. 3:1001-1008. http://dx.doi.org/10.1053/ajkd.2001.28589

Huet PM, Guillaum E, Cote J, Legare A, Lavoie P, Viallet A (1975). Noncirrhoitic Presinusoidal portal,hypertension associated with Chronic arsenical intoxication. Gastroenterology.68:1270-1277.

Ikem A, Osibanjo O, Sridhar MKC, Sobandea A (2002). Evaluation of groundwater quality Characteristics near two waste sites in Ibadan and Lagos, Nigeria. Water. Air Soil Pollutions.140:307-333. http://dx.doi.org/10.1023/A:1020165403531

Jarup L, Persson B, Elinder CG (1995). Decreased glomerular Filtration rate in cadmium exposed solderers. Occup. Environ. Med. 52:818822. http://dx.doi.org/10.1136/oem.52.12.818

Jones FT (2007). A Broad View of Arsenic. Poultry Science.86:2-14. http://dx.doi.org/10.1093/ps/86.1.2

Kaitantzian A, Kelepertzis E, Kelepertsis E (2013). Evaluation of the sources of contamination in the suburban area of KoropiMarkopouulo, Athens,Greece. Bull. Environ. Contamin. Toxicol. 91:23-28.http://dx.doi.org/10.1007/s00128-013-1023-6

Keleperzis $E$ (2014). Investigating the sources and potential health risks of environmental contaminants in the soils and drinking waters from the rural clusters in Thiva area (Greece). Ectotoxicol. Environ. Safety. 100:258-265. http://dx.doi.org/10.1016/j.ecoenv.2013.09.030

Kimete K, Islam K, Majlinda V, Majlinda V, Lirie S, Aferdita Z (2010). The level of heavy metals in several alternative water sources in the area Kastriot -Vushtrri-Drenas in Kosovo. BALWOIS.- Ohrid, Republic of Macedonia 25 -29 May. 1-11.

Lemy AD (1996). Evaluation of hazard quotient method for risk assessment of selenium. Ectotoxicology and Environmental safety. 35:156-162.

Moonis AK, Yuh -Sahn H (2011). Arsenic in Drinking water: A Review on Toxicological Effects, Mechanism of Accumulation and Remediation. Asian J Chem. 23:1889-1901.

Muhammed S, Shari MT, Khan S (2011). Health risk assessment of heavy metals and their source apportionment in drinking water of Kohistan region, northern Pakistan. Michrochem. J. 98:334-343. http://dx.doi.org/10.1016/j.microc.2011.03.003

Nabi Bidhendi GR, Karbassi AR, Nasrabadi T, Hoveidi H (2007). Influence of Copper mine on surface water Quality. Int. J. Environ. Sci. Tech. 4:85-91. http://dx.doi.org/10.1007/BF03325965

Nagehi $F$ (2012). Heavy metals distributions in Water of the Aras River, Ardabil, Iran. J. Water Resource Protection. Available at $\mathrm{http} / / \mathrm{www}$. readPeriodicals.com/201202/262332851htm.

National Population Commission of Nigeria (NPC) (2006). Population Census 2006. NPC Lagos, Nigeria.

Nordberg G, Jin T, Bernard A, Fierens S, Buchet JP (2002). Low bone density and renal dysfunction following environmental cadmium exposure in China. Ambio. 6:478-481.

Nwagozie IL, Ogelle E (2007). Water quality modeling of Rice - irrigated Obinna River Basin, Uzo uwani, Water, Air and Soil Pollution.100:197-212. http://dx.doi.org/10.1023/A:1018363205367

Ogunlaja A, Ogunlaja OO (2007). Physico -chemical Analysis of water sources in Ubeji community and their histological impact on organs of albino mice. J. Appl. Sci. Environ. Manage. 11:91-94.

Oyeku T, Eludoyin AO (2010). Heavy metal contamination of groundwater resources in a Nigerian Urban settlement. Afr. J. Envrion. Sci. Tech. 4: 207-214.

Singh KP, Malik AD, Sinha S (2005). Water Quality Assessment and Apportionment of pollution sources of Gomti River (India) using multivariate statistical Techniques: A case study. Chimica Acta. 538:355-374. http://dx.doi.org/10.1016/j.aca.2005.02.006
Ubachukwu PO (2004). Local Disease perception and treatment of enchocerciasis in uzo uwani Local Government Area of Enugu state, Nigeria. Animal Res. Int. 1:23-30.

United States Centre for Disease Control (US-CDC). (2011). Iron overload and Hemochromalosis. Centre for Disease control. March 28.

Uzo-uwani Professional Association (UPA) (2010). Our strategy paper. Available at www.uzouwaniprofessional.blogspot.com.

USEPA (2010), Integrated Risk Information System (IRIS). United States Environment Protection. Available online: http//www.Epa.Gov/irrris/index.infml (accessed October 2011).

Van Wijnen JH (1982). Health Risk Assessment in relation to soil pollution (Vogelmeer) (in Dutch) Tr. Soc. Geneesk. 60:555-559.

Veerkamp W, Ten Berge W (1990). Hazard Assessment of chemical contaminants in soil, ECETOC Technical Report 40 Brussels. European Chemical Industry Ecology and Toxicology Centre.

Wang X, Wang F, Chem B, Sun F, He W, Wen Di L, Si Wang Q (2012). Comparing the health risk of toxic metals through vegetable consumption between industrial polluted and non - polluted fields in Siaoguan; south China. J. Food, Agric. Environ. 10(2):943-948.

World Health Organization (WHO). (1995). Lead. Environmental Health Criteria.165. Geneva. World Health Organization.

World Health Organization (WHO) (2008). World Health Organization guidelines for Drinking water. Vol. 1. Geneva. 